Click www.researchjournal.co.in/online/subdetail.html to purchase.

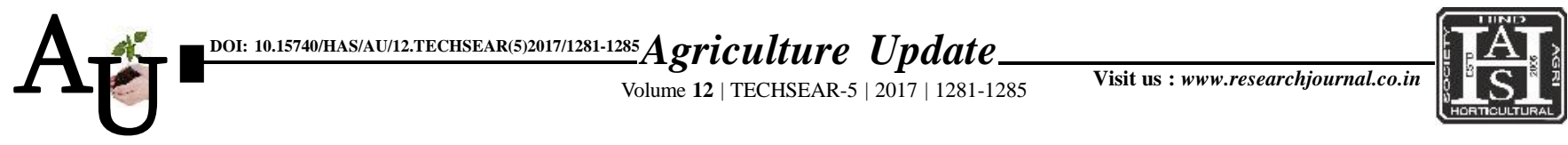

\title{
Research Article: Studies on organic manures and liquid organic manures to quality parameters in sweet corn [Zea mays (L.) Saccharata]
}

B.R. WAGHMODE, PRASAD M. PATIL AND R.K. SATHE

Article Chronicle : Received :

15.07.2017;

Accepted :

30.07.2017

KEY WoRdS :

Sweet corn, Organic

manures, Liquid

organic manures,

Fertilizer,

Dehydrogenase

activity, Quality

Author for correspondence :

B.R. WAGHMODE

Department of

Agronomy, College of

Agriculture, University

of Agricultural Sciences,

DHARWAD (KARNATAKA)

INDIA

Email :

waghmodebaburao@

gmail.com

See end of the article for

authors' affiliations
SUMMARY : The experiment has twenty four treatment combinations comprising of six main plots, organic manures mainly green leaf manure (GLM), enriched compost, FYM and vermicompost in combinations compared with RDF and FYM + RDF and four sub plots, liquid organic manures mainly bio-digester liquid manure, panchagavya and cow-urine. The treatments comprised of application of $7.5 \mathrm{tFYM}+\mathrm{RDF}\left(100: 50: 25 \mathrm{~N}, \mathrm{P}_{2} \mathrm{O}_{5}, \mathrm{~K}_{2} \mathrm{O} \mathrm{kg} \mathrm{ha}{ }^{-1}+10 \mathrm{~kg} \mathrm{ZnSO}_{4}\right)(\mathrm{RPP})$ and $\left(100: 50: 25 \mathrm{~N}, \mathrm{P}_{2} \mathrm{O}_{5}, \mathrm{~K}_{2} \mathrm{O} \mathrm{kg}\right.$ $\mathrm{ha}^{-1}+10 \mathrm{~kg} \mathrm{ZnSO}_{4}$ ) (RDF) alone exhibited significant effects on quality parameters viz., protein content, reducing and non-reducing sugar, total sugar, total soluble solids and total carbohydrates content in sweet corn kernels of sweet corn. Among the organic manurial combinations GLM + EC + VC (top dressing at GGS) recorded higher quality of sweet corn with all liquid organic manures over basal applied vermicompost. Similarly, Bio-digester and cow urine @ 10\% spray noticed higher quality of sweet corn over control. Irrespective of organic manures, the dehydrogenase activity was significantly higher with GLM + FYM + VC (top dressing at GGS) and GLM + EC + VC (basal) equivalent to RDN over RPP and RDF.

How to cite this article : Waghmode, B.R., Patil, Prasad M. and Sathe, R.K. (2017). Studies on organic manures and liquid organic manures to quality parameters in sweet corn [Zea mays (L.) Saccharata]. Agric. Update, 12(TECHSEAR-5) : 1281-1285; DOI: 10.15740/HAS/AU/12.TECHSEAR(5)2017/12811285. 